\title{
Synergistic effects of $\mathrm{CeO}_{2}$-supported bimetallic $\mathrm{Ni}-\mathrm{Cu}, \mathrm{Co}-\mathrm{Cu}$, and $\mathrm{Ni}-\mathrm{Fe}$ catalysts on steam reforming of ethanol
}

\author{
Takanori SAEKI, Hironobu OHKITA, Noriyoshi KAKUTA and Takanori MIZUSHIMA ${ }^{\dagger}$ \\ Department of Environmental and Life Sciences, Toyohashi University of Technology, \\ 2-1 Hibarigaoka, Tempaku-cho, Toyohashi, Aichi 441-8580, Japan
}

The synergistic effects of $\mathrm{CeO}_{2}$-supported bimetallic $\mathrm{Ni}-\mathrm{Cu}, \mathrm{Co}-\mathrm{Cu}$, and $\mathrm{Ni}-\mathrm{Fe}$ catalysts on the reduction properties, crystal structure, and catalytic performance during steam reforming of ethanol were investigated. Both metals in the bimetallic catalysts were reduced at lower temperatures than were the metals in the associated monometallic catalysts, and they formed alloy crystallites. It was confirmed from activity tests of the monometallic catalysts that $\mathrm{Ni}$ and $\mathrm{Co}$ were relatively active components and that $\mathrm{Cu}$ and $\mathrm{Fe}$ were less active. The combination of $\mathrm{Ni}$ and $\mathrm{Co}$ with $\mathrm{Cu}\left(\mathrm{Ni}-\mathrm{Cu} / \mathrm{CeO}_{2} \text { and } \mathrm{Co}-\mathrm{Cu} / \mathrm{CeO}\right)_{2}$ resulted in increases in $\mathrm{H}_{2}$ and $\mathrm{CO}_{2}$ yields and inhibition of carbon deposition during reactions at $673 \mathrm{~K}$. On the other hand, the incorporation of $\mathrm{Ni}$ with $\mathrm{Fe}\left(\mathrm{Ni}-\mathrm{Fe} / \mathrm{CeO}_{2}\right)$ showed a lower activity than did $\mathrm{Ni} / \mathrm{CeO}_{2}$ at $673 \mathrm{~K}$ but exhibited a higher $\mathrm{H}_{2}$ yield and higher resistance to carbon deposition at $873 \mathrm{~K}$, in which case NiFe alloys were formed. These results indicate the advantages of alloying a catalytically active metal with a less active metal during steam reforming of ethanol.

(C)2015 The Ceramic Society of Japan. All rights reserved.

Key-words : Ethanol steam reforming, $\mathrm{CeO}_{2}$-supported catalyst, Bimetallic alloy, Synergistic effect, Carbon deposition

[Received March 23, 2015; Accepted July 23, 2015]

\section{Introduction}

Hydrogen fuel has attracted attention as a clean energy source because it generates only water upon burning. However, its major drawback is that enormous quantities of carbon dioxide (a greenhouse gas) are emitted during its industrial production from petroleum and natural gas; therefore, other manufacturing approaches are desired. Steam reforming of ethanol (SRE), which is characterized by the reaction

$$
\mathrm{C}_{2} \mathrm{H}_{5} \mathrm{OH}+3 \mathrm{H}_{2} \mathrm{O} \rightarrow 2 \mathrm{CO}_{2}+6 \mathrm{H}_{2},
$$

is a promising method of producing hydrogen from biomass ethanol. ${ }^{1-3)}$ Carbon dioxide is also generated in this process, but its net quantity in the atmosphere can be assumed constant because it is absorbed during the growth of the plants that are raw materials for biomass ethanol. Hence, biomass ethanol is widely accepted as an environmentally friendly energy source.

It is well known that noble metals such as $\mathrm{Ru}, \mathrm{Rh}, \mathrm{Pd}$, and $\mathrm{Pt}$ exhibit catalytically high activities. ${ }^{4-7)}$ Apart from the noble metals, Ni and Co have also been used for SRE because of their high activities and low costs. ${ }^{8)-15)}$ We previously investigated the effects of metal oxide support in SRE over supported $\mathrm{Ni}$ catalysts ${ }^{16)}$ and found that $\mathrm{Al}_{2} \mathrm{O}_{3}$ and $\mathrm{MgO}$ supports partially formed solid solutions with $\mathrm{Ni}$ and consequently hindered its reduction and catalytic activity. $\mathrm{ZrO}_{2-}$ and $\mathrm{SiO}_{2}$-supported $\mathrm{Ni}$ catalysts had relatively high activities at $673 \mathrm{~K}$ but large amounts of carbon were deposited during the reaction. As a result, $\mathrm{CeO}_{2}$ was adopted as the support in this study because it promotes the reduction of the $\mathrm{Ni}$ ions to metallic crystallites that act as the catalytically active sites and, consequently, leads to high activ-

\footnotetext{
Corresponding author: T. Mizushima; E-mail: mizushima@ens.tut. ac.jp
}

ities at low temperatures. In addition, the $\mathrm{CeO}_{2}$ support inhibits carbon deposition during the reaction.

The bimetallic effects of SRE have been investigated for Ni$\mathrm{Cu},{ }^{17)-21)} \mathrm{Ni}-\mathrm{Co},{ }^{22), 23)} \mathrm{Ni}-\mathrm{Fe},{ }^{24), 25)}$ and $\mathrm{Ni}-\mathrm{Pt}^{26)-28)}$ Wang et al. ${ }^{19)}$ found that the unsupported $\mathrm{Ni}-\mathrm{Cu}$ catalyst exhibited stable performance, while the Ni catalyst showed severe deactivation due to heavy coke deposition. A decrease in carbon deposition was also reported for $\mathrm{Co}-\mathrm{Ni}$ supported on perovskite-type $\mathrm{LaFeO}_{3}{ }^{23)} \mathrm{Chen}$ et $\mathrm{al}^{20)}$ investigated the effect of the $\mathrm{Cu} / \mathrm{Ni}$ ratio on SRE over $\mathrm{Cu}-\mathrm{Ni} / \mathrm{SiO}_{2}$ catalysts and concluded that adding $\mathrm{Ni}$ to $\mathrm{Cu}$ catalysts improves $\mathrm{C}-\mathrm{C}$ bond rupture in ethanol, inducing synergistic enhancement in ethanol conversion at temperatures below $673 \mathrm{~K}$. Shi et al. ${ }^{24)}$ reported that bimetallic Ni-Fe catalysts supported on $\mathrm{La}_{2} \mathrm{O}_{2} \mathrm{CO}_{3}$ exhibited higher activities than did monometallic catalysts, which was attributed to the coexistence of well-dispersed $\mathrm{Ni}, \mathrm{Fe}$, and $\mathrm{LaFe}_{y} \mathrm{Ni}_{1-y} \mathrm{O}_{3}$. Moraes et al. ${ }^{28)}$ found that the $\mathrm{Ni} /$ $\mathrm{CeO}_{2}$ catalyst for low temperature SRE significantly deactivated during the reaction due to the formation of a nickel carbide phase. Pt addition minimized the formation of a nickel carbide phase and consequently enhanced catalyst activity and decreased catalyst deactivation. As mentioned above, the combination of metallic components is expected to improve catalytic performance in SRE.

In the present study, we investigated the bimetallic effects of $\mathrm{CeO}_{2}$-supported $\mathrm{Ni}-\mathrm{Cu}, \mathrm{Co}-\mathrm{Cu}$, and $\mathrm{Ni}-\mathrm{Fe}$ catalysts on the reduction properties, crystal structure, and catalytic performance during SRE. As mentioned in our previous report, ${ }^{16)} \mathrm{Ni}$ and $\mathrm{Co}$ catalysts supported on $\mathrm{CeO}_{2}$ maintained high activities for long reaction times, in spite of relatively large amounts of carbon deposition, whereas $\mathrm{Cu}$ and $\mathrm{Fe}$ catalysts were significantly deactivated by very small amounts of carbon. The objective of this investigation was to elucidate the effects of combining the catalytically active $\mathrm{Ni}$ and $\mathrm{Co}$ with the less active $\mathrm{Cu}$ and $\mathrm{Fe}$ supported on pure $\mathrm{CeO}_{2}$. 


\section{Experimental}

\subsection{Catalyst preparation}

Three types of $\mathrm{CeO}_{2}$-supported bimetallic catalysts, denoted by $\mathrm{Ni} 5 \mathrm{Cu} 5(5 \mathrm{wt} \% \mathrm{Ni}-5 \mathrm{wt} \% \mathrm{Cu}), \mathrm{Co} 5 \mathrm{Cu} 5(5 \mathrm{wt} \% \mathrm{Co}-5 \mathrm{wt} \% \mathrm{Cu})$, and $\mathrm{Ni} 5 \mathrm{Fe} 5$ ( $5 \mathrm{wt} \% \mathrm{Ni}-5 \mathrm{wt} \% \mathrm{Fe}$ ), were prepared. The $\mathrm{CeO}_{2}$ support was synthesized via a precipitation method. ${ }^{29)}$ Precursory precipitation was obtained by stirring a mixed solution $(500 \mathrm{~mL})$ of $\mathrm{Ce}\left(\mathrm{NO}_{3}\right)_{3} \cdot 6 \mathrm{H}_{2} \mathrm{O}(11.9 \mathrm{~g})$ and urea $(50 \mathrm{~g})$ at $363 \mathrm{~K}$, followed by filtration, washing with water, drying at $383 \mathrm{~K}$ for $12 \mathrm{~h}$, and then calcination at $773 \mathrm{~K}$ for $5 \mathrm{~h}$. The BET surface area of the resultant $\mathrm{CeO}_{2}$ powder was $110 \mathrm{~m}^{2} \cdot \mathrm{g}^{-1}$. Each catalyst was prepared by an impregnation method using commercial $\mathrm{Ni}\left(\mathrm{NO}_{3}\right)_{2} \cdot 6 \mathrm{H}_{2} \mathrm{O}$, $\mathrm{Co}\left(\mathrm{NO}_{3}\right)_{2} \cdot 6 \mathrm{H}_{2} \mathrm{O}, \mathrm{Cu}\left(\mathrm{NO}_{3}\right)_{2} \cdot 3 \mathrm{H}_{2} \mathrm{O}$, and $\mathrm{Fe}\left(\mathrm{NO}_{3}\right)_{3} \cdot 9 \mathrm{H}_{2} \mathrm{O}$ (Kishida Chemical). The $\mathrm{CeO}_{2}$ support was immersed in a mixed solution of the metal nitrates and evaporated to dryness in a boiling water bath. After drying at $383 \mathrm{~K}$ for $12 \mathrm{~h}$, the obtained powder was calcined at $773 \mathrm{~K}$ for $3 \mathrm{~h}$. For comparison, $\mathrm{CeO}_{2}$-supported monometallic $\mathrm{Ni}, \mathrm{Co}, \mathrm{Cu}$, and $\mathrm{Fe}$ catalysts with metal loadings of 10 wt \% (Ni10, Co10, Cu10, and Fe10, respectively) were also prepared in the same manner.

\subsection{Characterization}

The crystal structure of the catalysts was analyzed by X-ray diffraction (XRD) using a Rigaku Rint2000 diffractometer with Ni-filtered $\mathrm{Cu} \mathrm{K}_{\alpha}$ radiation generated at an accelerating voltage of $30 \mathrm{kV}$ and a tube current of $30 \mathrm{~mA}$. For the reduced catalysts, a liquid paraffin coating was employed to prevent sample reoxidation. The temperature-programmed reduction (TPR) was recorded with an apparatus consisting of a flow controller, a reaction tube, an electric furnace, and a thermal conductivity detector (Shimadzu GC-8A). The sample was heated at a temperatureincrease rate of $10 \mathrm{~K} \cdot \mathrm{min}^{-1}$ in a flow of $10 \% \mathrm{H}_{2} / \mathrm{Ar}$. Carbon deposited on the catalyst during the reaction was examined via thermogravimetry (TG) (Rigaku TG8120 Thermo Plus Evo) in air, at a temperature-increase rate of $10 \mathrm{~K} \cdot \mathrm{min}^{-1}$.

\subsection{Activity test}

The catalytic activity was evaluated in two types of reaction: temperature-programmed SRE (TP-SRE) at 473-873 K, with a stepwise temperature increase of $50 \mathrm{~K}$ per $30 \mathrm{~min}$, and isothermal $\mathrm{SRE}$ at 673 and $873 \mathrm{~K}$. For each reaction, the unreduced catalyst $(0.2 \mathrm{~g})$ was loaded into a tubular quartz reactor (ID $8 \mathrm{~mm})$. A mixed solution of $\mathrm{H}_{2} \mathrm{O} / \mathrm{C}_{2} \mathrm{H}_{5} \mathrm{OH}$ with a molar ratio of $3: 1$ was fed into the reactor at $30 \mu \mathrm{L} \cdot \mathrm{min}^{-1}$, vaporized at the top of the reactor, and then sent to the catalyst bed using a nitrogen flow of $30 \mathrm{~mL} \cdot \mathrm{min}^{-1}$. The gaseous products were passed through an icechilled trap in order to remove any liquids and then analyzed using two gas chromatograms with thermal conductivity detectors (Shimadzu GC-8A): one, for $\mathrm{H}_{2}$ detection, was equipped with a column packed with a $13 \mathrm{X}$ molecular sieve and used nitrogen as the carrier gas; the other, for detection of $\mathrm{C} 1$ gases $\left(\mathrm{CO}, \mathrm{CO}_{2}\right.$, and $\left.\mathrm{CH}_{4}\right)$, was equipped with a column packed with active carbon and used helium as the carrier gas. The product yields, $Y\left(\mathrm{H}_{2}\right)$ and $Y(\mathrm{C} 1)$, were calculated according to the ideal SRE equation, Eq. (1), with

$$
Y\left(\mathrm{H}_{2}\right)(\%)=\frac{F\left(\mathrm{H}_{2}\right)}{6 \times F\left(\mathrm{C}_{2} \mathrm{H}_{5} \mathrm{OH}\right)} \times 100
$$

and

$$
Y(\mathrm{C} 1)(\%)=\frac{F(\mathrm{C} 1)}{2 \times F\left(\mathrm{C}_{2} \mathrm{H}_{5} \mathrm{OH}\right)} \times 100,
$$

where $F\left(\mathrm{C}_{2} \mathrm{H}_{5} \mathrm{OH}\right)$ represents the feed rate of $\mathrm{C}_{2} \mathrm{H}_{5} \mathrm{OH}$ in $\mathrm{mol} \cdot \mathrm{min}^{-1}$, and $F\left(\mathrm{H}_{2}\right)$ and $F(\mathrm{C} 1)$ respectively represent the quantities of $\mathrm{H}_{2}$ and $\mathrm{C} 1$ gases produced in $\mathrm{mol} \cdot \mathrm{min}^{-1}$. The quantitative determination of ethanol and liquid products in the trap was difficult because of their tiny amounts and the poor sensitivity of the gas chromatogram, and therefore the catalytic performance was evaluated via $Y\left(\mathrm{H}_{2}\right)$ and $Y(\mathrm{C} 1)$ in the present investigation.

\section{Results and discussion}

\subsection{Reduction property and crystalline structure}

Figure 1 shows the TPR profiles of the $\mathrm{CeO}_{2}$-supported monometallic and bimetallic catalysts. The XRD patterns of the catalysts before and after reduction at $473-873 \mathrm{~K}$ for $1 \mathrm{~h}$ with hydrogen are also given in Fig. 2. The TPR profile of $\mathrm{Cu} 10$ is characterized by two partially overlapping peaks with small widths and high intensities, and demonstrates that $\mathrm{Cu} 10$ is reduced at the lowest temperatures among the monometallic catalysts. Ni10 and Co10 required higher reduction temperatures of 510-575 and 540-590 K, respectively. These are consistent with the XRD results that the $\mathrm{CuO}$ crystallites in $\mathrm{Cu} 10$ were reduced to the metal at $473 \mathrm{~K}$, whereas the oxide phases in Ni10 and Co10 remained at $473 \mathrm{~K}$ but were reduced to the metal phases at $573 \mathrm{~K}$. On the other hand, the TPR and XRD profiles of Fe10 indicate that the oxidized $\mathrm{Fe}$ species in the as-prepared catalyst are reduced at high temperatures above $650 \mathrm{~K}$. The less reducibility of $\mathrm{Fe} 10$ is attributable to a strong interaction with the $\mathrm{CeO}_{2}$ support and a partial formation of $\mathrm{Fe}-\mathrm{Ce}-\mathrm{O}$ solid solution. $^{30)}$

The bimetallic $\mathrm{Ni} 5 \mathrm{Cu} 5$ and $\mathrm{Co} 5 \mathrm{Cu} 5$ catalysts yielded the sharp and intense TPR peaks due to the reduction of the $\mathrm{Cu}$ oxide phases, which were obviously shifted to the lower temperatures compared to $\mathrm{Cu} 10$, indicating a bimetallic effect on the $\mathrm{Cu}$ reducibility. In addition, small TPR peaks are also observed promptly after the completion of the $\mathrm{Cu}$ reduction in Figs. 1(e) and 1(f). Although the reduction temperatures are much lower than those for Ni10 and Co10, these peaks can be assigned to the reductions of the Ni and Co species.

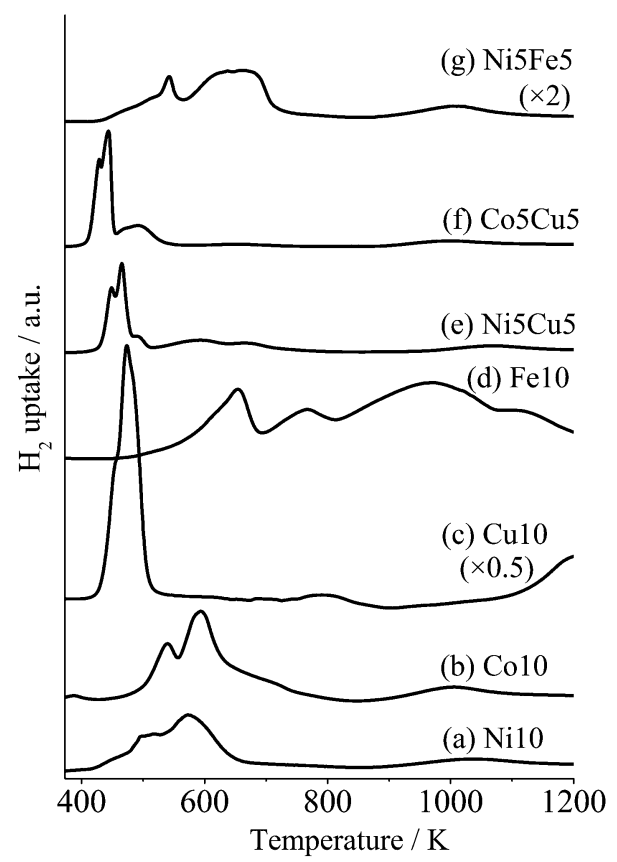

Fig. 1. TPR profiles of the $\mathrm{CeO}_{2}$-supported monometallic and bimetallic catalysts. 


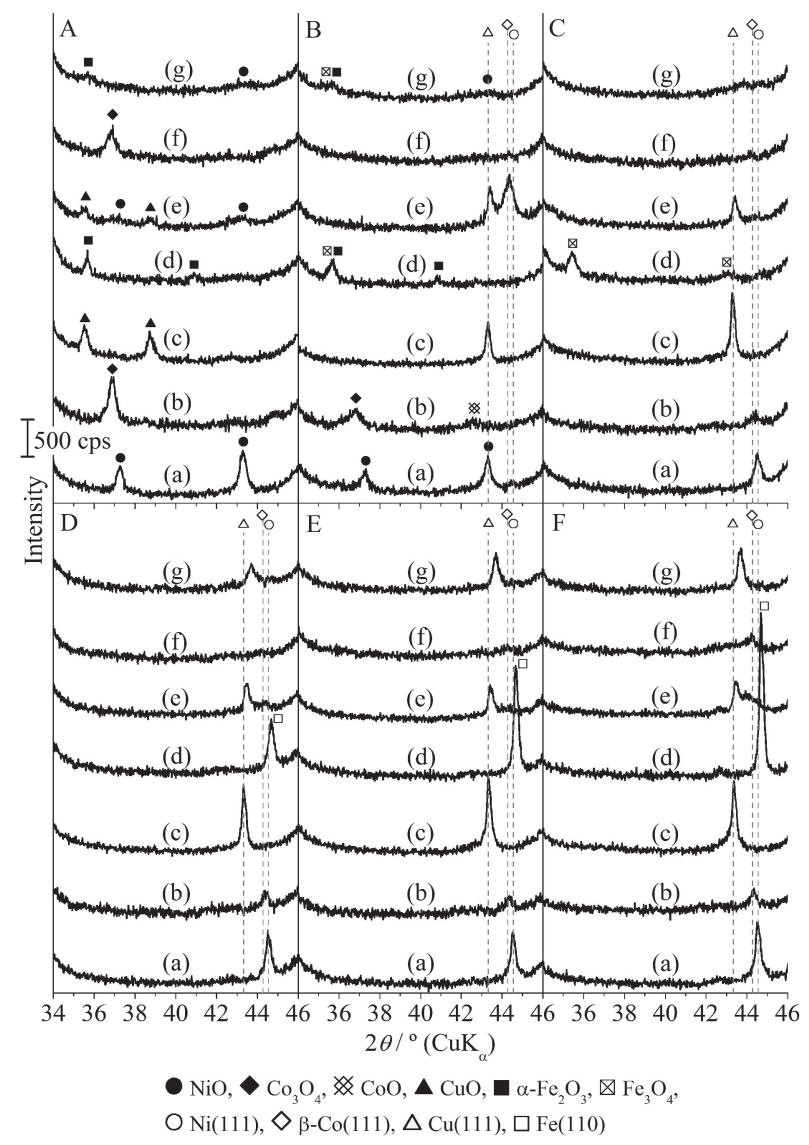

Fig. 2. XRD patterns of (a) Ni10, (b) Co10, (c) Cu10, (d) Fe10, (e) Ni5Cu5, (f) $\mathrm{Co} 5 \mathrm{Cu} 5$, and (g) Ni5Fe5 (A) before and (B) after reduction at $473 \mathrm{~K}$, (C) $573 \mathrm{~K}$, (D) $673 \mathrm{~K}$, (E) $773 \mathrm{~K}$, and (F) $873 \mathrm{~K}$ with hydrogen for $1 \mathrm{~h}$.

A decrease in the reduction temperature of the $\mathrm{Ni}$ phase in $\mathrm{Ni} 5 \mathrm{Cu} 5$ was also confirmed by XRD. A comparison between Figs. $2 \mathrm{~A}(\mathrm{e})$ and $2 \mathrm{~B}(\mathrm{e})$ clearly demonstrates that not only $\mathrm{CuO}$ but also $\mathrm{NiO}$ crystallites are reduced to the metals even at $473 \mathrm{~K}$ in contrast to the non-reduced behavior of Ni10. The diffraction angles of 43.42 and $44.36^{\circ}$ for the two peaks in Fig. 2B(e) fall between those for the 111 reflections from pure $\mathrm{Cu}\left(43.33^{\circ}\right)$ and $\mathrm{Ni}\left(44.55^{\circ}\right)$ crystals. This feature clearly indicates the formation of $\mathrm{Cu}-$ and Ni-rich alloy particles with face-centered cubic (fcc) structures. ${ }^{31)}$ Raising the reduction temperature to $573 \mathrm{~K}$ resulted in a marked decrease in the intensity of the XRD peak due to the Ni-rich alloys, but, at $873 \mathrm{~K}$, a very broad peak re-emerged at $43.8-44.9^{\circ}$, indicating the formation of very fine $\mathrm{NiCu}$ alloy particles having a wide variety of $\mathrm{Ni} / \mathrm{Cu}$ ratios.

The as-prepared $\mathrm{Co} 5 \mathrm{Cu} 5$ catalyst exhibited a broad XRD peak due to small $\mathrm{Co}_{3} \mathrm{O}_{4}$ crystallites, but no peak due to $\mathrm{Cu}$ was observed. After the hydrogen reduction at $473 \mathrm{~K}$, the peak due to the oxide disappeared and an extremely weak peak appeared at around $44.3^{\circ}$, which was identical to the diffraction angle of the 111 reflection from a cubic $\beta$-Co crystal. Finally, the peak slightly increased in intensity at a reduction temperature of $873 \mathrm{~K}$ and was accompanied by a tail toward the low-angle side, which suggests the formation of a $\mathrm{CoCu}$ alloy. ${ }^{32)}$

Ni5Fe5 yielded two major TPR peaks. The lower-temperature peak has a maximum at $543 \mathrm{~K}$ after a gradual increase in the $\mathrm{H}_{2}$ consumption. Although the peak temperature is about $30 \mathrm{~K}$ lower, this feature corresponds approximately to that of the oxidized $\mathrm{Ni}$ phase in Ni10. The broad TPR peak at $600-700 \mathrm{~K}$ is probably due to the reduction of the Fe species. A lack of the higher-temperature peaks above $750 \mathrm{~K}$ observed for Fe 10 may suggest that the broad peak consists of overlapped peaks due to the hardly reducible Fe species which are shifted to the lower temperatures by the presence of the reduced $\mathrm{Ni}$. The XRD results of Ni5Fe5 indicate that, at a reduction temperature of $573 \mathrm{~K}$, highly-dispersed $\alpha$ $\mathrm{Fe}_{2} \mathrm{O}_{3}$ and $\mathrm{NiO}$ particles were reduced to the crystallites which provided a weak peak at $43.9^{\circ}$. This peak increased in intensity with increasing temperature. The final diffraction angle of $43.7^{\circ}$ at $873 \mathrm{~K}$ indicates the formation of fcc $\mathrm{NiFe}$ alloy crystallites with a $\mathrm{Ni} / \mathrm{Fe}$ atomic ratio of about $1 .{ }^{33)}$

In conclusion, the combinations of $\mathrm{Ni}-\mathrm{Cu}, \mathrm{Co}-\mathrm{Cu}$, and $\mathrm{Ni}-\mathrm{Fe}$ resulted in the decreases in the reduction temperatures of both metals and the formations of the alloy crystallites. The improvements in the metal reducibilities are possibly caused by a synergistic interaction between the metal oxide phases and by a decrease in their crystallite size. ${ }^{34)}$ In addition, the significant decrease in the reduction temperatures of the less reducible metals is probably attributable to the catalytic effects of the more reducible metals.

\subsection{Catalytic performance and structure in SRE}

In addition to $\mathrm{H}_{2}$ and $\mathrm{CO}_{2}, \mathrm{CO}$ and $\mathrm{CH}_{4}$ were produced from ethanol mainly via the following reactions: ${ }^{1), 3), 35 \text { ) }}$

$$
\begin{aligned}
& \mathrm{C}_{2} \mathrm{H}_{5} \mathrm{OH}+\mathrm{H}_{2} \mathrm{O} \rightarrow 2 \mathrm{CO}+4 \mathrm{H}_{2} \\
& \mathrm{C}_{2} \mathrm{H}_{5} \mathrm{OH} \rightarrow \mathrm{CH}_{4}+\mathrm{CO}+\mathrm{H}_{2}
\end{aligned}
$$

The following are also accepted as the significant side reactions for the byproducts. ${ }^{1), 3), 35 \text { ) }}$

$$
\begin{aligned}
& \mathrm{CO}_{2}+\mathrm{H}_{2} \leftrightarrow \mathrm{CO}+\mathrm{H}_{2} \mathrm{O} \\
& \mathrm{CO}+3 \mathrm{H}_{2} \leftrightarrow \mathrm{CH}_{4}+\mathrm{H}_{2} \mathrm{O}
\end{aligned}
$$

It is well known that ethylene is also generated via dehydration of

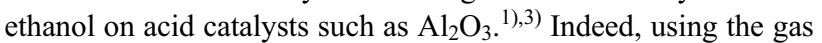
chromatogram, it was detected during SRE over $\mathrm{Al}_{2} \mathrm{O}_{3}$-supported catalysts, but it was not observed for the $\mathrm{CeO}_{2}$-supproted catalysts employed in this study.

The yields of $\mathrm{H}_{2}, \mathrm{CO}_{2}, \mathrm{CO}$, and $\mathrm{CH}_{4}$ for TP-SRE over the $\mathrm{CeO}_{2}$-supported monometallic and bimetallic catalysts are shown in Fig. 3. The $\mathrm{Cu}$-containing catalysts $(\mathrm{Cu} 10, \mathrm{Ni} 5 \mathrm{Cu} 5$, and $\mathrm{Co} 5 \mathrm{Cu} 5)$ began to produce $\mathrm{H}_{2}$ even at $523 \mathrm{~K}$. In contrast, the other catalysts (Ni10, Co10, Fe10, and Ni5Fe5) generated $\mathrm{H}_{2}$ at reaction temperatures of $\geq 623 \mathrm{~K}$. As mentioned above, the metal oxides in the $\mathrm{Cu}$-containing catalysts were reduced to the metal and alloy crystallites at temperatures below $523 \mathrm{~K}$, whereas the remaining catalysts required higher reduction temperatures. These results suggest that the metallic phases are the catalytically active sites for SRE.

The $\mathrm{H}_{2}$ yield for $\mathrm{Cu} 10$ was relatively high at $\leq 573 \mathrm{~K}$, but its increase with increasing temperature was attenuated above $600 \mathrm{~K}$. This behavior was probably caused by carbon deposition on the $\mathrm{Cu}$ surfaces. ${ }^{16)} \mathrm{Ni10}$ was characterized by the generation of a large amount of $\mathrm{CH}_{4}$ and a related decrease in $\mathrm{H}_{2}$ yield at $723-$ $823 \mathrm{~K}$. In contrast, Ni5Cu5 strongly suppressed them and consequently maintained relatively high $\mathrm{H}_{2}$ yields across the whole temperature range. $\mathrm{Co} 5 \mathrm{Cu} 5$ also exhibited higher $\mathrm{H}_{2}$ yields than both $\mathrm{Co} 10$ and $\mathrm{Cu} 10$ at $623-723 \mathrm{~K}$, and its activity was maintained as high as that of Co10 at higher temperatures. Although Fe10 was comparatively less active, the addition of $\mathrm{Fe}$ to $\mathrm{Ni} /$ $\mathrm{CeO}_{2}(\mathrm{Ni5Fe} 5)$ inhibited $\mathrm{CH}_{4}$ formation over the $\mathrm{Ni}$ atoms and improved the yields of $\mathrm{H}_{2}$ and $\mathrm{CO}_{2}$ at $773-823 \mathrm{~K}$.

Figure 4 shows the product yields $9 \mathrm{~h}$ after the initiation of SRE at 673 and $873 \mathrm{~K}$ over the monometallic and bimetallic 


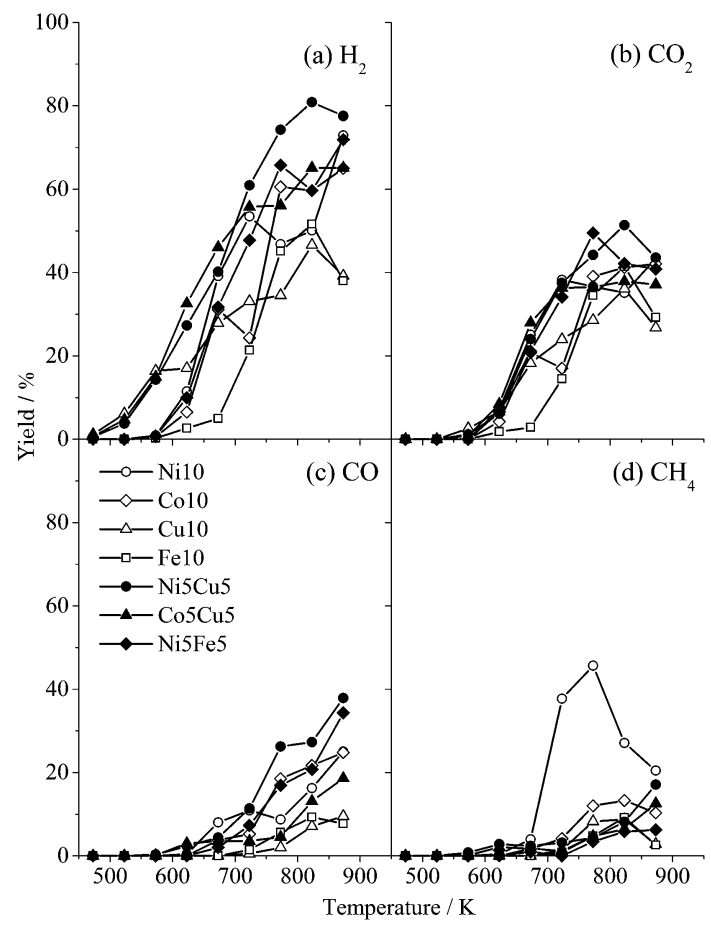

Fig. 3. Product yields for temperature-programmed SRE over the $\mathrm{CeO}_{2}$-supported monometallic and bimetallic catalysts.

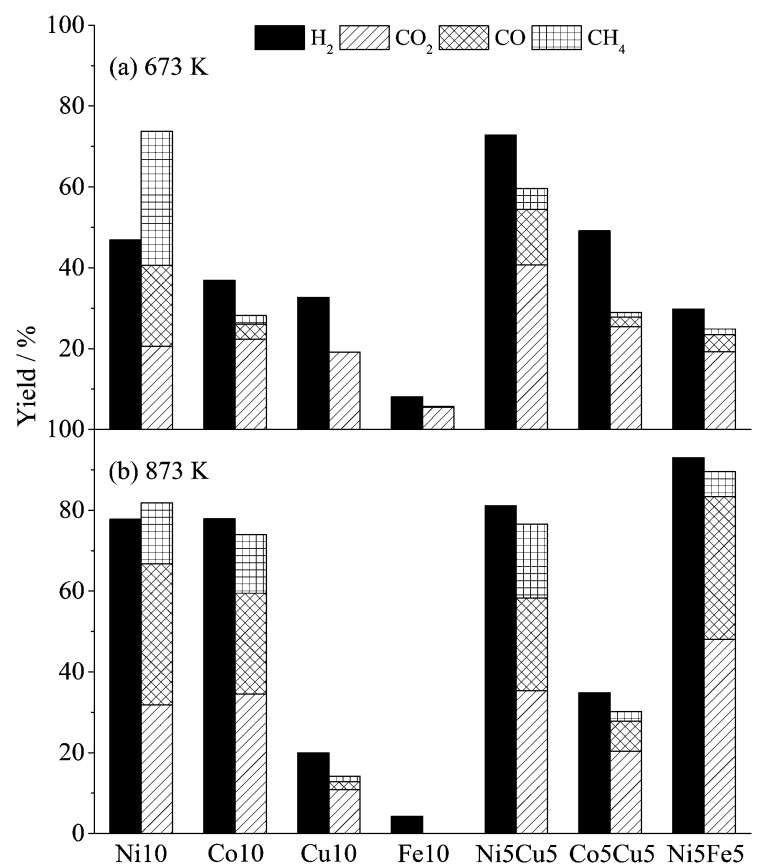

Fig. 4. Product yields at $9 \mathrm{~h}$ after the initiation of SRE at (a) $673 \mathrm{~K}$ and (b) $873 \mathrm{~K}$ over the $\mathrm{CeO}_{2}$-supported monometallic and bimetallic catalysts.

catalysts. Ni10, Co10, and Cu10 exhibit relatively high $\mathrm{H}_{2}$ yields, but $\mathrm{Fe} 10$ was less active at $673 \mathrm{~K}$. In addition, Ni10 produced much larger amounts of $\mathrm{CO}$ and $\mathrm{CH}_{4}$, but these were not detected for $\mathrm{Cu} 10$. By raising the reaction temperature to $873 \mathrm{~K}$, Ni10 and Col0 increased in the activities but $\mathrm{Cu} 10$ and Fe10 were inactivated by carbon deposition. ${ }^{16)}$

At $673 \mathrm{~K}$, the addition of $\mathrm{Cu}$ to $\mathrm{Ni} / \mathrm{CeO}_{2}(\mathrm{Ni} 5 \mathrm{Cu} 5)$ resulted in a significant decrease in $\mathrm{CH}_{4}$ and a significant increase in $\mathrm{H}_{2}$ and

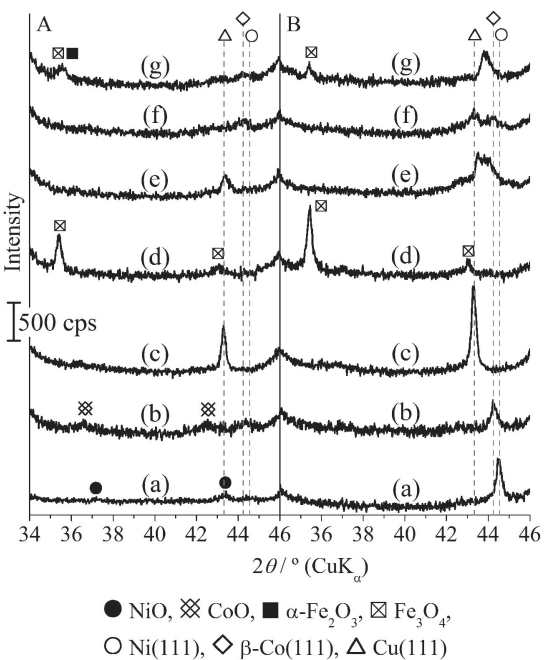

Fig. 5. XRD patterns of (a) Ni10, (b) Co10, (c) Cu10, (d) Fe10, (e) Ni5Cu5, (f) Co5Cu5, and (g) Ni5Fe5 after SRE at (A) $673 \mathrm{~K}$ and (B) $873 \mathrm{~K}$ for $9 \mathrm{~h}$.

$\mathrm{CO}_{2}$. $\mathrm{Co} 5 \mathrm{Cu} 5$ also exhibits a higher $\mathrm{H}_{2}$ yield than both $\mathrm{Co} 10$ and $\mathrm{Cu} 10$. These results clearly indicate the synergistic effects of a combination of the two metals. However, these effects were not observed at $873 \mathrm{~K}$. In contrast, although $\mathrm{Ni5Fe} 5$ yielded no bimetallic effect at $673 \mathrm{~K}$, it exhibited the highest yields of $\mathrm{H}_{2}$ and $\mathrm{C} 1$-gases, and the inhibitory effect of the $\mathrm{CH}_{4}$ formation at $873 \mathrm{~K}$. As a result, the advantages of $\mathrm{Ni5Cu} 5$ and $\mathrm{Co} 5 \mathrm{Cu} 5$ at $673 \mathrm{~K}$ and of $\mathrm{Ni} 5 \mathrm{Fe} 5$ at $873 \mathrm{~K}$ over the monometallic catalysts demonstrate the effectiveness of the combination of a catalytically active metal with a less active metal.

The XRD patterns of the catalysts after SRE at 673 and $873 \mathrm{~K}$ for $9 \mathrm{~h}$ are shown in Fig. 5. At a reaction temperature of $673 \mathrm{~K}$, $\mathrm{Cu} 10$ was completely reduced to the metal, but the unreduced oxides were detected for the other monometallic catalysts, indicating a less reducibility during SRE than during hydrogen reduction at the same temperature. On the other hand, the bimetallic $\mathrm{Ni} 5 \mathrm{Cu} 5$ and $\mathrm{Co} 5 \mathrm{Cu} 5$ catalysts exhibited no XRD peak due to the oxides phase. The XRD peak observed for Ni5Cu5 is located at a slightly larger diffraction angle than is the 111 reflection from the $\mathrm{Cu}$ crystallites in $\mathrm{Cu} 10$. In addition, it is asymmetric and slightly broadened to the high-angle side, and therefore assigned to $\mathrm{Cu}$ rich $\mathrm{NiCu}$ alloy particles. $\mathrm{Co} 5 \mathrm{Cu} 5$ also yielded an asymmetric peak broadened to the low-angle side, which is due to $\mathrm{CoCu}$ alloy crystallites. These results demonstrate an improvement effect of the $\mathrm{Cu}$ doping on the reducibility of $\mathrm{Ni}$ and $\mathrm{Co}$ which may contribute to enhance the catalytic activities at $673 \mathrm{~K}$. In the case of the less active Ni5Fe5 catalyst, the peak due to $\mathrm{Fe}$ oxides was observed but the peak due to $\mathrm{NiFe}$ alloys was not. The alloy phases were formed by raising the reaction temperature to $873 \mathrm{~K}$, at which $\mathrm{Ni5Fe} 5$ exhibited the excellent catalytic properties. These results clearly indicate that the bimetallic effects on SRE are strongly associated with the alloy formations.

Figure 6 shows the TG profiles of the catalysts employed for SRE at 673 and $873 \mathrm{~K}$ for $9 \mathrm{~h}$. The total quantities of the carbon deposits, estimated from the weight losses, are also summarized in Table 1. The weight losses due to the combustion of deposited carbon are classified into two groups: small weight loss at 490$570 \mathrm{~K}$ and relatively large weight loss at $\geq 600 \mathrm{~K}$. As mentioned in our previous report, ${ }^{16)}$ the latter is attributed to the combustion of fibrous carbon deposited on the highly active Ni10 and Co10. On the other hand, the carbon related to the former weight loss 


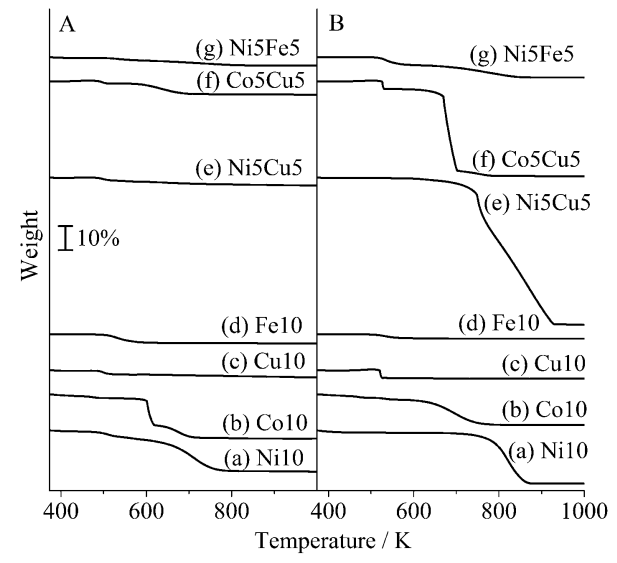

Fig. 6. TG profiles of the $\mathrm{CeO}_{2}$-supported monometallic and bimetallic catalysts after SRE at (A) $673 \mathrm{~K}$ and (B) $873 \mathrm{~K}$ for $9 \mathrm{~h}$.

Table 1. The amount of deposited carbon after SRE at $673 \mathrm{~K}$ and $873 \mathrm{~K}$ for $9 \mathrm{~h}$

\begin{tabular}{cccccccc}
\hline $\begin{array}{c}\text { Reaction } \\
\text { temp. } \\
{[\mathrm{K}]}\end{array}$ & $\mathrm{Ni10}$ & $\mathrm{Co10}$ & $\mathrm{Cu} 10$ & $\mathrm{Fe} 10$ & $\mathrm{Ni} 5 \mathrm{Cu} 5$ & $\mathrm{Co5Cu} 5$ & $\mathrm{Ni5Fe} 5$ \\
\cline { 2 - 8 } & 0.21 & 0.22 & 0.03 & 0.04 & 0.04 & 0.06 & 0.04 \\
$673 \mathrm{~K}$ & 0.21 & & & \\
$873 \mathrm{~K}$ & 0.28 & 0.14 & 0.03 & 0.02 & 1.58 & 0.65 & 0.09 \\
\hline
\end{tabular}

significantly deactivated $\mathrm{Cu} 10$ and $\mathrm{Fe} 10$ in spite of the very small amount that was undetectable by SEM. Although at $673 \mathrm{~K}$, $\mathrm{Ni} 5 \mathrm{Cu} 5$ and $\mathrm{Co} 5 \mathrm{Cu} 5$ exhibited higher activities than did Ni10 and Co10, respectively, carbon deposition was strongly inhibited. However, raising the reaction temperature to $873 \mathrm{~K}$ resulted in approximately 40- and 10-fold increases in carbons deposited on $\mathrm{Ni5Cu} 5$ and $\mathrm{Co} 5 \mathrm{Cu} 5$, respectively, most of which were the higher-temperature-combustible carbon generated on $\mathrm{Ni}$ and $\mathrm{Co}$. On the other hand, Ni5Fe5, which presented the best catalytic performance at $873 \mathrm{~K}$, showed excellent resistance to carbon deposition when compared with Ni10.

In conclusion, the combination of $\mathrm{Ni}$ and $\mathrm{Co}$ with $\mathrm{Cu}$ promoted their reductions to form the alloys during SRE at $673 \mathrm{~K}$, leading to the high catalytic activities and the inhibition of carbon deposition. Similar advantages of $\mathrm{Ni} 5 \mathrm{Fe} 5$ arose at $873 \mathrm{~K}$, in which case $\mathrm{NiFe}$ alloy crystallites were formed. These results demonstrate that the alloy formations are closely related to the improvement in the catalytic performances. Miranda et al. ${ }^{36)}$ reported that deep hydrogenolysis of glycerol to $\mathrm{CH}_{4}$ was inhibited by the addition of $\mathrm{Cu}$ to the $\mathrm{Ni} / \gamma-\mathrm{Al}_{2} \mathrm{O}_{3}$ catalyst. They also found, by IR spectroscopy, that the bridge-bonded $\mathrm{CO}$ adsorbed on metallic $\mathrm{Ni}$ progressively decreased due to the incorporation of $\mathrm{Cu}$, and they therefore concluded that $\mathrm{CH}_{4}$ formation requires an ensemble of adjacent active $\mathrm{Ni}$ atoms. Since $\mathrm{CH}_{4}$ generated in SRE not only reduces $\mathrm{H}_{2}$ production but also promotes carbon deposition via its decomposition, ${ }^{2,3)}$ a decrease in the adjacent array of active metal atoms by alloying with the less active metal is presumed to be useful in the inhibition of $\mathrm{CH}_{4}$ formation and the subsequent carbon deposition and thereby in the enhancement of $\mathrm{H}_{2}$ production.

\section{Conclusion}

In this study, we investigated the bimetallic effects of $\mathrm{CeO}_{2}-$ supported $\mathrm{Ni}-\mathrm{Cu}, \mathrm{Co}-\mathrm{Cu}$, and $\mathrm{Ni}-\mathrm{Fe}$ catalysts on SRE. A combination of the two metals on $\mathrm{CeO}_{2}$ decreased the reduction temperatures of both components and formed $\mathrm{NiCu}, \mathrm{CoCu}$, and $\mathrm{NiFe}$ alloys with fcc structures. $\mathrm{Ni} / \mathrm{CeO}_{2}$ had the highest ability among the monometallic catalysts to form $\mathrm{H}_{2}$ but produced a large amount of $\mathrm{CH}_{4}$ and deposited carbon. $\mathrm{Co} / \mathrm{CeO}_{2}$ also exhibited a relatively high activity, but the $\mathrm{Cu}$ and $\mathrm{Fe}$ catalysts were less active. Incorporation of $\mathrm{Ni}$ with $\mathrm{Cu}$ inhibited $\mathrm{CH}_{4}$ formation and heavy carbon deposition (which arose predominantly on Ni) and thereby enhanced the $\mathrm{H}_{2}$ yield. Similar synergistic effects were observed for the $\mathrm{Co}-\mathrm{Cu}$ catalyst. It was confirmed that alloy crystallites were formed in these catalysts during the reactions, leading to the adequate synergistic effects. However, these advantages were lost by raising the temperature to $873 \mathrm{~K}$. In the case of the Ni-Fe catalyst, the NiFe alloys were generated at a reaction temperature of $873 \mathrm{~K}$ and exhibited excellent catalytic performances. These improvements were probably generated by an ensemble effect of the alloy catalysts through which $\mathrm{CH}_{4}$ formation on an adjacent array of the active metal atoms was inhibited and $\mathrm{H}_{2}$ production was enhanced.

\section{References}

1) A. N. Fatsikostas, D. I. Kondarides and X. E. Verykios, Catal. Today, 75, 145-155 (2002).

2) A. Haryanto, S. Fernando, N. Murali and S. Adhikari, Energy Fuels, 19, 2098-2106 (2005).

3) M. Ni, D. Y. C. Leung and M. K. H. Leung, Int. J. Hydrogen Energy, 32, 3238-3247 (2007).

4) J. P. Breen, R. Burch and H. M. Coleman, Appl. Catal., B, 39, 65-74 (2002)

5) D. K. Liguras, D. I. Kondarides and X. E. Verykios, Appl. Catal., B, 43, 345-354 (2003).

6) A. Erdőhelyi, J. Raskó, T. Kecskés, M. Tóth, M. Dömök and K. Baán, Catal. Today, 116, 367-376 (2006).

7) A. C. Basagiannis, P. Panagiotopoulou and X. E. Verykios, Top. Catal., 51, 2-12 (2008).

8) J. Sun, X. Qiu, F. Wu and W. Zhu, Int. J. Hydrogen Energy, 30, 437-445 (2005).

9) M. C. Sánchez-Sánchez, R. M. Navarro and J. L. G. Fierro, Int. J. Hydrogen Energy, 32, 1462-1471 (2007).

10) A. L. Alberton, M. M. V. M. Souza and M. Schmal, Catal. Today, 123, 257-264 (2007).

11) R. Trane-Restrup, S. Dahl and A. D. Jensen, Int. J. Hydrogen Energy, 38, 15105-15118 (2013).

12) F. Haga, T. Nakajima, H. Miya and S. Mishima, Catal. Lett., 48, 223-227 (1997).

13) J. Llorca, N. Homs, J. Sales and P. Ramírez de la Piscina, J. Catal., 209, 306-317 (2002).

14) X. Pang, Y. Chen, R. Dai and P. Cui, Chin. J. Catal., 33, 281289 (2012).

15) J. Vicente, C. Montero, J. Ereña, M. J. Azkoiti, J. Bilbao and A. G. Gayubo, Int. J. Hydrogen Energy, 39, 12586-12596 (2014).

16) T. Saeki, H. Ohkita, N. Kakuta and T. Mizushima, J. Jpn. Petrol. Inst., accepted.

17) A. J. Vizcaíno, A. Carrero and J. A. Calles, Int. J. Hydrogen Energy, 32, 1450-1461 (2007).

18) A. C. Furtado, C. G. Alonso, M. P. Cantão and N. R. C. Fernandes-Machado, Int. J. Hydrogen Energy, 34, 7189-7196 (2009).

19) F. Wang, Y. Li, W. Cai, E. Zhan, X. Mu and W. Shen, Catal. Today, 146, 31-36 (2009).

20) L. Chen and S. D. Lin, Appl. Catal., B, 106, 639-649 (2011).

21) L. Zhang, J. Liu, W. Li, C. Guo and J. Zhang, J. Nat. Gas Chem., 18, 55-65 (2009).

22) L. Chen, C. K. S. Choong, Z. Zhong, L. Huang, Z. Wang and J. Lin, Int. J. Hydrogen Energy, 37, 16321-16332 (2012).

23) Z. Wang, C. Wang, S. Chen and Y. Liu, Int. J. Hydrogen Energy, 39, 5644-5652 (2014). 
24) Q. Shi, Z. Peng, W. Chen and N. Zhang, J. Rare Earths, 29, 861-865 (2011).

25) R. da Paz Fiuza, M. Aurélio da Silva and J. S. Boaventura, Int J. Hydrogen Energy, 35, 11216-11228 (2010).

26) F. Soyal-Baltacioğlu, A. E. Aksoylu and Z. I. Önsan, Catal. Today, 138, 183-186 (2008)

27) E. Örücü, F. Gökaliler, A. E. Aksoylu and Z. I. Önsan, Catal. Lett., 120, 198-203 (2008).

28) T. S. Moraes, R. C. R. Neto, M. C. Ribeiro, L. V. Mattos, M. Kourtelesis, S. Ladas, X. Verykios and F. B. Noronha, Catal. Today, 242, 35-49 (2015).

29) W. Cai, F. Wang, E. Zhan, A. C. Van Veen, C. Mirodatos and W. Shen, J. Catal., 257, 96-107 (2008).

30) K. Li, M. Haneda, P. Ning, H. Wang and M. Ozawa, Appl. Surf. Sci., 289, 378-383 (2014).
31) D. J. Chakrabarti, D. E. Laughlin, S. W. Chen and Y. A. Chang, "Phase diagrams of binary nickel alloys," Ed. by P. Nash, ASM International, Materials Park, OH (1991) pp. 85-95.

32) A. Casanovas, M. Roig, C. de Leitenburg, A. Trovarelli and J. Llorca, Int. J. Hydrogen Energy, 35, 7690-7698 (2010).

33) L. J. Swartzendruber, V. P. Itkin and C. B. Alcock, "Phase diagrams of binary nickel alloys", Ed. by P. Nash, ASM International, Materials Park, OH (1991) pp. 110-132.

34) J. H. Lin, P. Biswas, V. V. Guliants and S. Misture, Appl. Catal., A, 387, 87-94 (2010).

35) F. Haga, T. Nakajima, H. Miya and S. Mishima, Catal. Lett., 48, 223-227 (1997).

36) B. C. Miranda, R. J. Chimentão, J. Szanyi, A. H. Braga, J. B. O. Santos, F. Gispert-Guirado, J. Llorcae and F. Medina, Appl. Catal., B, 166-167, 166-180 (2015). 